This PDF is a selection from a published volume from the National Bureau of Economic Research

Volume Title: American Universities in a Global Market

Volume Author/Editor: Charles T. Clotfelter, editor

Volume Publisher: University of Chicago Press

Volume ISBN: 0-226-11044-3; 978-0-226-11044-8

Volume URL: http://www.nber.org/books/clot08-1

Conference Date: October 2-4, 2008

Publication Date: May 2010

Chapter Title: What Does Global Expansion of Higher Education Mean for the United States?

Chapter Author: Richard B. Freeman

Chapter URL: http://www.nber.org/chapters/c11602

Chapter pages in book: (373 - 404) 


\title{
What Does Global Expansion of Higher Education Mean for the United States?
}

\author{
Richard B. Freeman
}

University education, once the privilege of a modest number of well-to-do persons in high-income countries, spread massively throughout the world in the latter part of the twentieth century and beginning of the twenty-first century (Shofer and Meyer 2005). Between 1970 and 2006, the number of students enrolled in institutions of higher education increased from 29 million to over 141 million. The numbers studying science and engineering, where the content of courses is relatively similar around the world, increased commensurately. The global expansion of higher education eroded the U.S. position as the country with the most highly educated workforce and potentially endangers the U.S. lead in science and technology. In the 2000s, diverse business and academic groups issued reports that warned that the faster growth of the supply of science and engineering students overseas than in the United States risked national competitiveness and national security ( $\mathrm{Na}-$ tional Academy of Sciences 2005; Council of Competitiveness 2005).

In which countries has university education spread rapidly? Why have so many more students gone on to higher education outside the United States, and why have so many countries expanded their higher education system in the past thirty or so years? What are the implications for the United States? How might the country best respond to the rest of the world closing the higher education gap with the United States?

This study examines these questions in two stages.

Part I documents the global expansion in university training in terms of the increased proportion of young persons enrolled in university in advanced

Richard B. Freeman holds the Herbert Ascherman Chair in Economics at Harvard University, is the faculty director of the Labor and Worklife Program at Harvard Law School, and is a research associate of the National Bureau of Economic Research. 
countries; the increased absolute number of young persons obtaining university training in developing countries; the influx of women into higher education, which has brought the female share above 50 percent of university students in many advanced countries; and the growing number of international students from developing countries. The bottom line of part I is that the United States will continue to lose its quantitative edge in higher education, including science and engineering, in the foreseeable future.

Part II examines the implications of this development for the U.S. labor market, university system, and economy writ large. With respect to the labor market, the expansion of higher education overseas and the influx of international students in the United States have contributed to the growing supply of highly educated immigrants to the country. Because the U.S. higher educational system is the world leader, in the short and medium run, it benefits from the increased supply of students worldwide, as many of the world's best and brightest seek a U.S. education and later seek jobs at U.S. universities. But as the quality of higher education improves in other countries, their universities will invariably become more competitive with the American institutions in attracting students and faculty. The globalization of higher education should benefit the United States and the world economy by accelerating the rate of technological advance associated with science and engineering and speeding the adoption of best-practices around the world, which will lower the costs of production and prices of goods. But the increased number of graduates in other countries threatens U.S. comparative advantage in graduate-intensive sectors of production, particularly if the graduates cost much less than comparable U.S. workers. The United States has responded to the great increase of university graduates overseas by "importing" highly educated workers through immigration. U.S. firms have also off shored work to highly educated workers overseas. I conclude this essay by examining the benefits and costs of these two alternatives and considering government and university policies that might enhance the net benefits to the United States from the global expansion of higher education.

\subsection{Part I: Expansion of Higher Education}

Table 11.1 presents estimates of the number of persons enrolled in higher education worldwide and the U.S. proportion of world enrollees in selected years from 1970 to 2006. The data are from the UNESCO Institute for Statistics, which reports enrollments in "tertiary" education for most countries over this period. ${ }^{1}$ The figures are best viewed as giving orders of magnitudes

1. UNESCO Institute for Statistics (UIS) Data Centre, based on data provided by UNESCO Member States through the UIS annual data collection with most recent data from http://stats .uis.unesco.org/unesco/TableViewer/tableView.aspx?ReportId=175, table 3B, enrollment by 
Table 11.1

Millions of enrollments and shares of world enrollments in higher education, including enrollments for less than four years, by country, 1970-2006

\begin{tabular}{|c|c|c|c|c|}
\hline & 1970 & 1980 & 1990 & 2006 \\
\hline \multicolumn{5}{|c|}{ Millions of enrollments } \\
\hline World & 29.4 & 55.3 & 67.6 & 141.5 \\
\hline United States & 8.5 & 12.1 & 13.7 & 17.5 \\
\hline Other advanced & 4.9 & 8.2 & 12.9 & 29.5 \\
\hline Developing $^{\mathrm{a}}$ & 16 & 35 & 41 & 102.5 \\
\hline China & $<0.1$ & 1.7 & 1.8 & 23.4 \\
\hline India & 2.5 & 3.5 & 5 & 12.9 \\
\hline \multicolumn{5}{|c|}{ Shares of world enrollments $(\%)$} \\
\hline United States & 29.00 & 22.00 & 20.00 & 12.00 \\
\hline Other advanced & 16.70 & 14.8 & 20.3 & 17.7 \\
\hline Developing $^{\mathrm{a}}$ & 54.4 & 63.3 & 60.7 & 72.4 \\
\hline China & 0 & 3.1 & 2.7 & 16.5 \\
\hline India & 8.5 & 6.3 & 7.4 & 9.1 \\
\hline
\end{tabular}

Source: UNESCO, online files: http://stats.uis.unesco.org/TableViewer/tableView.aspx?Report $\mathrm{Id}=47 ; \mathrm{http}: / / \mathrm{www}$.uis.unesco.org/en/stats/centre.htm; http://www.uis.unesco.org/pagesen/ DBGTerIsced.asp.

Note: The UNESCO Web site also reports table II.S.3 enrollment by level of education for major areas and groups of countries. The UNESCO division of countries between advanced and developing shows an even greater increase from 1970 in the developing country share. My division places the ex-Soviet countries in the group outside the United States and other advanced countries.

${ }^{a}$ Developing indicates developing and other countries beyond the United States and advanced.

rather than precise statistics. One reason is that definitions of tertiary education and counts of students vary across countries. Another reason is that UNESCO does not report data annually for every country so that to get numbers for some countries in a given year, I used data from the nearest surrounding year. Even with a large window to find a near year with data (going back to 2000 in a few cases to obtain estimates for 2006), data for some countries was still missing (such as Sri Lanka, Syria, and Serbia, among others). Finally, the UNESCO database lacks information for the ex-Soviet Union, ex-Yugoslavia, and the two Germanys from 1970 to $1997 .^{2}$ To deal with this problem, I used enrollment figures from the Banks Cross National Time Series Archives. ${ }^{3}$ While it is likely that data from national sources are

International Standard Classification of Education (ISCED) level enrollment in total tertiary. See also http://stats.uis.unesco.org/unesco/TableViewer/tableView.aspx?ReportId=167, table 14 , tertiary indicators.

2. http://www.uis. unesco.org/en/stats/centre.htm; http://www.uis.unesco.org/pagesen/ DBGTerIsced.asp.

3. Cross National Time Series Data Archive, 2004 Arthur S. Banks, http://www.databanks international.com. 
more accurate than UNESCO figures, for consistency, I use the UNESCO data for all countries, including the United States.

The table shows that in 1970, approximately 29 percent of the world's college students were in the United States, although the country had approximately 6 percent of the world's population. ${ }^{4}$ Thereafter, the U.S. share of world college enrollments dropped rapidly so that by 2005 to 2006, the United States had 12 percent of enrollments - about two-fifths of its 1970 share. During this period, tertiary enrollments in other advanced countries went from barely half of U.S. enrollments to 23 percent greater than U.S. enrollments; while enrollment in developing countries, most spectacularly China, increased by such large numbers that in 2006 nearly three-quarters of the world's tertiary-level enrollments were in those countries. Chinese government statistics (Ministry of Education of the People's Republic of China 2007), which differ somewhat from the UNESCO data, show an increase in full time enrollment from 924,000 in 1993 to 5.4 million students in 2006 and an increase in total enrollment from 5 million to 25 million, or from 5 percent to 22 percent of the age cohort over the same period. ${ }^{5}$

Table 11.2 turns to the number of first university degrees and the number relative to the number of twenty-four-year-olds in the United States compared to the rest of the world in 2004. It gives the number of bachelors' degrees in total, the number in the natural sciences and engineering, the number of twenty-four-year-olds, and the numbers of degrees relative to the number of twenty-four-year-olds for the United States and the world, respectively. Column (1) records these figures for the United States. Column (2) records these statistics for the world. Column (3) shows the ratio of the U.S. numbers to the world numbers. The United States had 14 percent of all bachelor's degrees and 9 percent of science and engineering degrees, compared to about 5 percent of the world's twenty-four-year-olds. The proportion of twenty-four-year-olds earning first degrees and earning first degrees in natural science and engineering was larger in the United States than in the world.

Table 11.3 examines the changing position of the United States in the world's production of first degrees overall and in natural science and engineering from 1995 to 2004. Because the National Science Foundation (NSF) reports degrees only for three regions for 1995-Europe, Asia, and North America - the trend data compare the United States to those regions. The 1995 to 2004 trend shows that the U.S. share of bachelor's degrees fell by 8 points, while the U.S. share of natural science and engineering degrees

4. The United States had such a large proportion because it developed the first mass higher education system in the world. Land grant colleges gave opportunities for university education throughout the country. The GI Bill spurred enrollments in colleges and universities. Refugees from Europe contributed to building first-rate science and engineering research programs. Sputnik led to large investments in R\&D and university education.

5. www.albertachina.com/upload/IB_BEIJING-_123071-v1-China_Higher_education. 
Numbers of degrees and 24-year-olds in the United States compared to world, and ratios of degrees to 24-year-olds, 2004

\begin{tabular}{lccc}
\hline & $\begin{array}{c}\text { United States } \\
(1)\end{array}$ & $\begin{array}{c}\text { World } \\
(2)\end{array}$ & $\begin{array}{c}\text { Ratio, United } \\
\text { States/World } \\
(3)\end{array}$ \\
\hline $\begin{array}{l}\text { First degrees, total (in thousands) } \\
\text { First natural science/engineering degrees }\end{array}$ & 1,407 & 10,926 & 0.14 \\
$\quad$ (in thousands) & 236 & 2,772 & 0.09 \\
$\begin{array}{l}\text { 24-year-olds } \\
\text { Proportion of 24-year-olds with first degrees }\end{array}$ & 3,850 & 79,360 & 0.05 \\
$\begin{array}{l}\text { Proportion of 24-year-olds with natural } \\
\quad \text { science/engineering first degrees }\end{array}$ & 0.37 & 0.14 & 2.64 \\
\hline
\end{tabular}

Source: National Science Board (2008), Science and engineering indicators, 2008, appendix table 2-37, where the number of degrees is for 2004 or the most recent year. Number of 24-year-olds from National Science Board (2006), Science and engineering indicators, 2006, appendix table 2-37, where the number of 24-year-olds refers to 2002 or the most recent year.

Table 11.3 Ratios and changes in numbers of degrees and 24-year-olds in the United States relative to comparable numbers for Three Regions (Asia, Europe, North America), 1995-2004

\begin{tabular}{|c|c|c|c|}
\hline & \multicolumn{2}{|c|}{$\begin{array}{l}\text { Ratio, United States/ } \\
\text { Three Regions }\end{array}$} & \multirow{2}{*}{$\begin{array}{c}\text { Change in ratios, } \\
1992-2004\end{array}$} \\
\hline & 1992 & 2004 & \\
\hline First degrees, total (in thousands) & 0.23 & 0.15 & -0.08 \\
\hline $\begin{array}{l}\text { First natural science/engineering degrees } \\
\text { (in thousands) }\end{array}$ & 0.13 & 0.10 & -0.02 \\
\hline 24-year-olds & 0.06 & 0.06 & 0.0 \\
\hline $\begin{array}{l}\text { Proportion of 24-year-olds with first } \\
\text { degrees }\end{array}$ & 4.10 & 2.50 & -1.60 \\
\hline $\begin{array}{l}\text { Proportion of 24-year-olds with natural } \\
\text { science/engineering first degrees }\end{array}$ & 2.35 & 1.61 & -0.74 \\
\hline
\end{tabular}

Sources: 1995, calculated from National Science Board (1998), Science and engineering indicators, 1998 , appendix table 2-1, where the number of degrees and 24 year olds is for 1995 or the most recent year. 2004, calculated from National Science Board (2004), Science and engineering indicators, 2008, appendix table 2-37, and National Science Board (2006), Science and engineering indicators, 2006, appendix table 2-37, for Asia, Europe, and North America.

Note: The ratios measure the relevant statistic for the United States divided by the statistic for Asia, Europe, and North America because those are the only areas for which the National Science Board provides data.

declined by 2 points, and that the U.S. edge in first degrees and in first degrees in natural science and engineering per twenty-four-year-old fell commensurately. Data on degrees for the entire world would presumably show the U.S. share of degrees declining by larger amounts than in table 11.3 because enrollments grew rapidly in areas with missing degree data - South America, Africa, and Oceana. 
Given that the United States has about 5 percent of world population and that most of the rest of the world is in catch-up mode in mass higher education, the decline in the U.S. advantage in the proportion of the population with university training is likely to continue for some time.

\subsubsection{PhD Graduates in Science and Engineering}

The $\mathrm{PhD}$ is the critical degree for advanced research and, thus, for increasing the stock of knowledge on which economic growth ultimately depends. Table 11.4 records the ratios of $\mathrm{PhDs}$ earned in science and engineering in major $\mathrm{PhD}$ producing countries relative to the numbers in the United States from 1975 to 2004. PhDs in science and engineering outside the United States increased sharply, while the number granted in the United States stabilized at about 26,000 per year before increasing modestly to 29,000 by 2006. In 2004, the European Union (EU) granted 78 percent more science and engineering (S\&E) PhDs than the United States.

The greatest growth in $\mathrm{PhDs}$ granted is in China. In 1975, China produced almost no science and engineering doctorates. In 2004, NSF figures show that the country graduated $23,000 \mathrm{PhDs}$, approximately 63 percent in science and engineering. Between 1995 and 2003, first-year entrants in PhD programs in China increased sixfold, from 8,139 to 48,740. At this rate, China will produce more science and engineering doctorates than the United States by 2010. The quality of doctorate education surely suffers from such rapid expansion, so the numbers should be discounted, but as the new Chinese doctorate programs develop, quality will undoubtedly improve.

Within the United States, moreover, international students have come to earn an increasing proportion of S\&E PhDs. In 1966, universities awarded

Table 11.4

Ratio of science/engineering (S\&E) PhDs from foreign universities to U.S. universities and U.S. share of world S\&E PhDs, 1975-2010

\begin{tabular}{lccccc}
\hline & 1975 & 1989 & 2001 & 2004 & 2010 \\
\hline Asia major nations & & & \\
China & 0.22 & 0.48 & 0.96 & 1.23 & n.a. \\
Japan & n.a. & 0.05 & 0.32 & 0.57 & 1.26 \\
European Union major (France, Germany, United Kingdom) & 0.11 & 0.16 & 0.29 & 0.29 & n.a. \\
All advanced European Union $^{\mathrm{b}}$ & 0.64 & 0.84 & 1.07 & 1.02 & n.a. \\
Chinese "diaspora"/United States $^{\mathrm{c}}$ & 0.93 & 1.22 & 1.54 & 1.78 & 1.92 \\
U.S. share of world science/engineering PhDs $^{\text {n.a. }}$ & n.a. & 0.72 & n.a. & n.a. \\
\hline
\end{tabular}

Sources: National Science Board (2008), Science and engineering indicators, 2008: table 2-40; 2002: table 2-36; Weigo and Zhaohui National Research Center for S\&T Development (China), private communication; NSF (1993, 1996).

${ }^{a}$ China, Japan, India, Korea.

${ }^{b}$ Includes Norway, Switzerland, excludes new European Union entrants, extrapolation to 2010.

"Diaspora" includes estimates of Chinese doctoral graduates from the United Kingdom, Japan, and the United States (with temporary visas). U.S. natives = citizens and permanent residents. 
23 percent of science and engineering $\mathrm{PhDs}$ to the foreign-born; 71 percent to U.S.-born males and 6 percent to U.S.-born females. In 2006, universities awarded 48.2 percent of science and engineering $\mathrm{PhDs}$ to the foreign-born; 26.3 percent to U.S.-born males and 25.5 percent to U.S.-born females. ${ }^{6}$ Looking among fields, the foreign-born received 23.2 percent of all doctorates awarded in the social and behavioral sciences, 32.3 percent in the life sciences, 50.6 percent in the physical sciences, and 63.6 percent in engineering. Because few U.S. students earn S\&E PhDs overseas, the ratio of S\&E PhDs earned by U.S. citizens or residents to those earned by citizens of other countries fell more rapidly than the ratio of degrees granted by U.S. universities to degrees granted by foreign universities. If we add the number of S\&E PhDs granted to Chinese students in the United States and other countries to the numbers granted in China, the ratio of Chinese degrees to U.S. PhDs granted less those given to the Chinese rose to 0.71 in 2001. But because many Chinese who gain PhDs in the United States remain in the United States, it is more appropriate to count them as part of the U.S. supply than of the supply of S\&E PhDs in China.

\subsubsection{Propensity to Enroll and Graduate: Advanced Countries}

The Organization for Economic Cooperation and Development (OECD) and NSF provide data on the proportions of young persons enrolling and graduating university. Table 11.5 displays the rank of the United States in "entry rates" into tertiary education and in first-time graduation relative to the relevant age group in 1992 and 2005 from the OECD data. ${ }^{7}$ In 1992, the United States was second (to Canada) in entry rates and third in graduation rates among the twenty or so OECD countries that reported data. In 2004, the United States was seventh and thirteenth, respectively. The lower ranking of the United States in graduation rates than in entry rates reflects what the OECD calls the low "survival rate" of students in the United States, where a smaller proportion of entrants to higher education graduate with four-year degrees than in other advanced countries. The United States was tied for seventeenth position of the eighteen countries in the OECD survival rate data. The table also displays the rank of the United States in bachelor's graduates overall and in the natural sciences and engineering relative to the age group in 1992 and 2004 (based on NSF data). The United States has a lower rank in natural science and engineering degrees per twenty-fouryear-old than in all bachelor's degrees per twenty-four-year-old because Americans are less likely to major in science and engineering than students in other countries.

Comparing the proportion of workers with college degrees across

6. The 1966 figures are from Freeman, Jin, and Shen (2007); the 2006 from NSB (2008).

7. These are cumulated entry rates for countries so that if 20 percent of twenty-year-olds enter tertiary education and 21 percent of twenty-one-years-olds enter, the rate is 41 percent. 
Table 11.5

U.S. rank in propensity for university training, 1992-2005

\begin{tabular}{lcr}
\hline \multicolumn{3}{c}{ Graduation data from OECD/NSF } \\
\hline \\
\hline "Tertiary A" graduation rates (OECD) & 1992 & 2005 \\
Bachelor's degrees/24-year-olds (NSF) & 2 of 15 & 13 of 20 \\
Natural science \& engineering/24-year-olds (NSF) & 2 of 21 & 14 of 23 \\
PhD or equivalent graduation rates (OECD) & 3 of 21 & 19 of 23 \\
All science graduates/25-34-year-olds (OECD) & n.a. & 9 of 20 \\
\hline
\end{tabular}

Enrollment data from OECD

\begin{tabular}{lcr}
\hline & 1995 & \multicolumn{1}{c}{2005} \\
\hline First time entry as percentage of age group & 2 of 15 & 7 of 20 \\
Enrollment percentage of $20-29$-year-olds & 9 of 20 & 12 of 20
\end{tabular}

Survival rates for advanced countries from OECD

Graduation/new entrants for type A

2004,17 tie out of $18^{\mathrm{a}}$

Sources: OECD, Education at a Glance, 2005; NSB, Science and Engineering Indicators (various years).

Notes: OECD $=$ Organization for Economic Cooperation and Development; NSF $=$ National Science Foundation. n.a. = not available.

a 17 th out of 18 tie means that the United States is tied for 17 th out of 18 countries in the comparison.

cohorts/age groups provides another way to document the declining relative position of the United States in higher education. Because most graduates obtain their degree in their twenties, the share of persons with degrees in different age groups reflects the share of young persons earning degrees when the age group was in their twenties at different time periods. The OECD data on higher educational attainment by age group show that in all of the advanced countries save the United States, the proportion with university education is much higher in younger than older age groups. In the United States, there is little difference in the graduate shares by age. The implication is that the college share of young persons stabilized in the United States while growing among other advanced countries over this period. ${ }^{8}$

It is natural, at least for labor economists, to wonder if the differences in the shares or changes in the shares of young persons investing in higher education across countries are related to cross-country differences in the economic payoff to higher education. Within countries, college-going appears

8. See OECD (2005), Education at a Glance 2005: OECD indicators, table A1.3a. Regressions of the ln of the college share of each age group and a trend indicator for when the group was in the age group of the youngest cohort, twenty-five to thirty-four years old (four for age twentyfive to thirty-four; three for age thirty-five to forty-four; two for age forty-five to fifty-four; and one for age fifty-five to sixty-four) give a 0.028 coefficient on time in the United States with a standard error nearly as large. By contrast, the coefficient on the time indicator for the other countries was 0.19 with a standard error one-fourth the size. 
to respond to differences in returns, measured in various ways (Freeman 1975, 1976; Edin and Topel 1997). To see if there is a similar relation between returns and college-going across countries, I display the proportions of young persons graduating university and OECD estimates of the ln wage differential between university graduates and secondary school graduates in figure 11.1, and the proportion of young persons graduating and estimated internal rates of return to investing in higher education that take account of costs of tuition, among other factors, in figure 11.2 (Baorini and Strauss 2007). Because recent graduates make up only a small proportion of the overall college graduate population, the relative earnings or rates of return

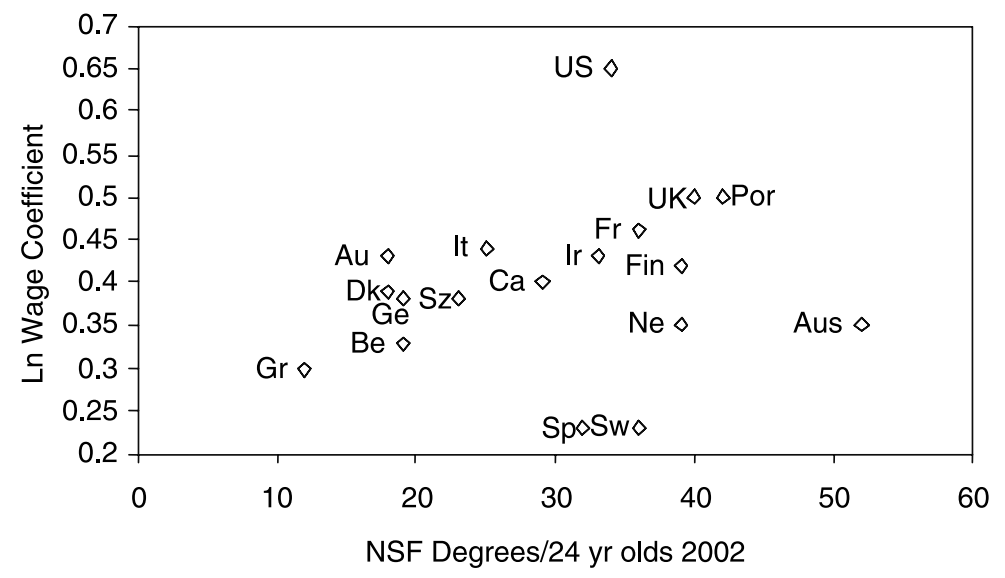

Fig. 11.1 OECD estimated Ln wage coefficient and proportion of twenty-fouryear-olds getting bachelor's degree $(r=0.19)$

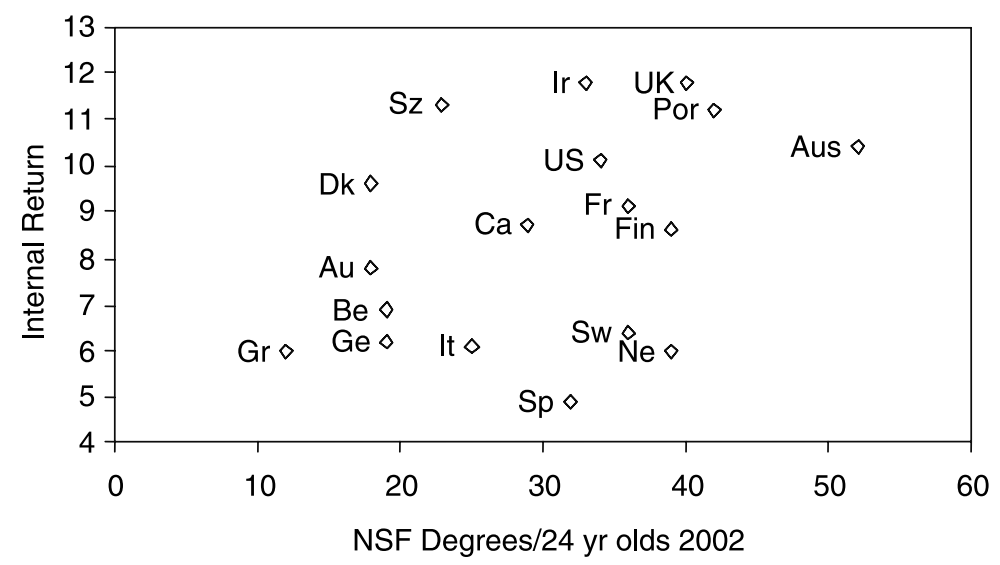

Fig. 11.2 OECD estimated internal rate of return to college degree and proportion of twenty-four-year-olds getting bachelor's degree $(r=0.39)$ 
for all university graduates should be largely exogenous to the supply of the youngest group. Put differently, the earnings differentials for the stock of graduates would be determined by the interaction of current demand conditions with the supply of all graduates set years or decades earlier per the "cobweb type" models of the market for graduates (Freeman 1971). Thus, the relation between the flow of new graduates and earnings differentials or rates of return should largely reflect supply behavior and, thus, be positively related.

Figure 11.1 shows that, indeed, there is a modest positive correlation $(r=$ 0.19 ) between the earnings differentials and the influx of young graduates relative to the population among the OECD countries. One reason the correlation is modest is that consistent with its high level of earnings inequality, the United States has the largest coefficient on higher education in the ln earnings equation, but only a moderate rate of college-going. Another reason the correlation is modest is that at the other end of the spectrum, countries with narrow distributions of earnings and low college/high school wage differentials, such as Sweden, have high enrollment ratios despite their low earnings differentials. Sweden graduates approximately three times as many $\mathrm{PhDs}$ in science and engineering relative to the age group as does the United States, despite having a lower return to post-bachelor's education!

What might explain the weak correlation between the coefficients on college education and the proportions going to university in these data? One possible factor is that the earnings regressions do not take account for the direct costs of college-going, which differs greatly between the United States, with its high tuition, and European countries. To deal with this and differential taxes and other factors that may influence the return, the OECD calculated internal rates of return using comparable cross-country earnings data for individuals. Figure 11.2 shows that the relation between the OECD estimated internal rate of return and the proportions earning degrees is stronger than is the relation between the earnings differentials themselves and the proportion graduating university $(r=0.39)$. But again, there is a lot of variation. Three of the countries with higher rates of graduation than the United States have higher internal rates of return per labor supply behavior, but four of the countries with higher rates of college graduation than the United States have lower estimated internal rates of return. Three of those low rate of return countries, Sweden, the Netherlands, and Finland, have compressed earnings distributions in general and low tuition, which would make investments in university training less risky than in the United States and might make smaller differentials in earnings more meaningful as signals of opportunity than in the United States.

In any case, these calculations show that while high returns to university training have driven some of the growth of investing in higher education in advanced countries, there is sufficient country variation for other factors, 
including educational and earnings policies that do not directly affect private monetary returns, to also affect enrollment and graduation rates.

\subsubsection{China and India}

The huge and increased numbers of university graduates in China and India have attracted attention as part of the discussion of the offshoring of computer programming and multinational corporate investments in research in those countries. In 2005, top executives from high-tech firms reported that China graduated as many as ten times the number of engineers as the United States and that India also graduated more engineers than the United States to call for policies to increase the supply of science and engineering graduates in the United States. More detailed investigation, however, found that part of the reported China/India to U.S. gap in engineering degrees reflected comparisons of numbers with different definitions of degrees (Duke University 2005; Wadwha et al. 2008). Chinese and Indian data included graduates from short courses comparable to U.S. two-year degree programs, while the U.S. data excluded computer science degrees that the other countries counted with engineering. Adjusting the numbers for comparability brings the United States, China, and India numbers closer but does not overturn the trend growth of degrees in China and India compared to the United States. It simply displaces the increase in four-year comparable degree production two to three years behind the publicized figures.

The massive growth of university graduates in China in the 2000s created a major problem in the Chinese job market even before the world economy fell into the most devastating recession since the 1930s. The Chinese government estimated that approximately 1.5 million graduates of the graduating class of 2008 were unemployed over a year later-for an unemployment rate of over 20 percent. ${ }^{9}$ With 6.1 million graduates coming onto the labor market, in 2009, Chinese Premier Wen Jiabao declared that employment of higher education graduates was a priority for the government. The state encouraged graduates to find jobs at the urban and rural grassroots in poorer western regions and in small- and medium-sized businesses rather than sitting jobless in big coastal cities. ${ }^{10}$

The extent to which the huge supplies and joblessness of graduates in China and other developing countries will create problems for university graduates in the United States depends in part on the quality of the education received in those countries. In an effort to determine the qualifications of new graduates in developing countries, the McKinsey Global Institute (2005) asked recruiters for multinational firms to estimate the proportion

9. Jamil Anderlini, "China Battles Unemployment to Deter Unrest," Financial Times, December 21, 2008, http://www.ft.com/cms/s/0/fa2ecbc2-cf76-11dd-abf9-000077b07658.html ?nclick_check $=1$.

10. Reuters, "China Pushes to Ease Grim Graduate Unemployment," January 7, 2009, http://www.reuters.com/article/worldNews/idUSTRE5062AD20090107. 
of graduates from different countries that might be suitable candidates for their firm in terms of skills and language and potential mobility. The recruiters estimated that in engineering, 10 percent of graduates from China and 25 percent of graduates from India were so qualified (McKinsey Global Institute 2005, exhibit 2, 8) and gave figures for graduates from most other developing countries in the same range. But it is difficult to know how to assess these estimates. The McKinsey survey did not ask whether graduates could perform successfully for subcontractor firms in their local area in their own language. It did not explore whether the lower pay of graduates in developing countries would compensate for the lower qualifications so that, while multinational firms might not hire them directly, those firms would subcontract work to firms with the less-qualified but cheaper graduate in the developing countries. Finally, the study never asked for the proportion of graduates from U.S. engineering schools that recruiters viewed as qualified.

\subsubsection{Surge of Women into Higher Education}

Underlying the increase in university enrollments and degrees has been a huge movement of women into higher education.

Table 11.6 shows the ratio of the proportion of females of college age attending university to the proportion of males of college age attending university in advanced countries, as reported by the OECD and by the United Nations (UN) for 2004. When the ratio of female to male enrollment rates is 1.0 , the same proportion of the relevant age group is in university. When the ratio is below 1.0, there are more men than women enrolled relative to the age group and, conversely, when the ratio is above 1.0. For most of the postWorld War II period and in earlier decades, university students consisted disproportionately of men. Beginning roughly in the 1970s, enrollments of women began to increase more rapidly than enrollments of men in virtually all advanced countries so that by 2004 , women made up a majority of university students in twenty-one of the twenty-five advanced countries in the table. The surge of women into higher education in the United States increased the ratio of female to male enrollments to above 1.0 at the bachelor's and master's level (which includes many school teachers) and just a bit below 1.0 for law, PhD, and MD enrollments as of 2006 (U.S. Census Bureau 2007). Among doctorates granted to the U.S.-born, the ratio of female to male $\mathrm{PhDs}$ rose to 1.03. In 2004, 22 percent more women than men were granted graduate research fellowships by the National Science Foundation, implying that the female to male ratio among $\mathrm{PhDs}$ in science and engineering will continue to rise.

Table 11.7 turns from female to male enrollments in the advanced countries to the female to male enrollments in the entire world. It shows the ratio of female to male enrollments in the world, for advanced and developing 


\section{Table 11.6}

Enrollment ratios of women and men in higher education, by age group, advanced countries, 2004

\begin{tabular}{lcc}
\hline Country & $\begin{array}{c}\text { Organization for Economic } \\
\text { Cooperation and Development }\end{array}$ & United Nations \\
\hline Norway & 1.54 & 1.38 \\
Iceland & 1.78 & 1.82 \\
Australia & 1.23 & 1.14 \\
Ireland & 1.28 & 1.28 \\
Sweden & 1.55 & 1.47 \\
Canada & 1.36 & n.a. \\
United States & 1.39 & 1.27 \\
The Netherlands & 1.08 & 1.17 \\
Finland & 1.20 & 1.26 \\
Luxembourg & 1.18 & $\mathrm{n} . \mathrm{a}$. \\
Portugal & 1.32 & $\mathrm{n} . \mathrm{a}$. \\
Germany & $\mathrm{n} . \mathrm{a}$. & 0.97 \\
Japan & 0.89 & 0.73 \\
Switzerland & 0.80 & 0.97 \\
Korea & 0.61 & 0.87 \\
Belgium & 1.21 & 1.06 \\
Austria & 1.19 & 1.24 \\
Denmark & 1.42 & 1.58 \\
France & 1.28 & 1.47 \\
Italy & 1.34 & 1.27 \\
United Kingdom & 1.37 & 1.17 \\
Spain & 1.22 & 1.41 \\
New Zealand & 1.41 & 1.41 \\
Israel & 1.33 & $\mathrm{n} . \mathrm{a}$. \\
Greece & 1.17 & 1.23 \\
\hline
\end{tabular}

Sources: OECD, Education Statistics at a Glance; United Nations.

Note: n.a. $=$ not available.

countries as a group, and in selected countries from 1988 to 2005 . Worldwide, the number of female to male enrollees increased by over 40 points in the period, putting the ratio above 1.0 in 2005 . The developing countries had lower ratios of female to male enrollments than the advanced countries but also had greater increases in the ratios. In China, female to male enrollments jumped from 0.55 to 0.95 . In Brazil, 32 percent more women than men were university students in 2005 . While in many countries in Africa, Latin America, and in the Arab world, the ratios are still noticeably below 1 , the direction of change is clear: feminization of higher education is proceeding rapidly around the world. As women contribute to an increasingly large supply of new university students, companies and countries whose institutions and policies (family friendly policies, most likely) allow them to attract and use female graduates efficiently are likely to have an edge in the marketplace. 
Table 11.7

Ratio of female to male tertiary enrollment rates

\begin{tabular}{lrr}
\hline Group/Country & 1988 & 2005 \\
\hline World & 64 & 105 \\
Advanced & 106 & 121 \\
United States & 116 & 140 \\
The Netherlands & 81 & 108 \\
All developing countries & 54 & 91 \\
Chile & 82 & 96 \\
Malaysia & 87 & 131 \\
Most populous developing countries & & \\
India & 47 & 70 \\
China & 55 & 95 \\
Indonesia & & 79 \\
Brazil & 106 & 132 \\
Pakistan & 88 \\
Bangladesh & 46 & 53 \\
Nigeria & 25 & 55 \\
Mexico & 66 & 99 \\
The Philippines & & 123 \\
Vietnam & & 71 \\
\hline
\end{tabular}

Source: UNESCO.

\subsubsection{International Students}

The proportion of students who study in countries other than their own has also been increasing rapidly since at least the mid-1970s. The first column of table 11.8 shows that from 1975 to 2005 , the number of international students increased from 0.6 million to 2.7 million - nearly fivefold. The second column shows that the number of international students to the United States increased somewhat more slowly over the whole period, from 0.15 million to 0.58 million - a bit less than fourfold. The third column shows the U.S. share of international students rising in the 1970s and then dropping in the late 1990 s to 2000 s. Although the U.S. share of international students fell in the latter period, the growth rate of international students in the United States was still sufficient to increase the international student share of U.S. enrollments.

Countries differ in the extent to which they recruit or attract international students at the undergraduate or graduate level. Some countries like Australia and, to a lesser extent, the United Kingdom specialize in undergraduate education for international students, whose tuition payments help fund higher education institutions that receive relatively modest government support and lack the endowments of U.S. private universities. By contrast, table 11.9 shows that the U.S. intake of international students consists disproportionately of graduate students, many in $\mathrm{PhD}$ programs. In addition, the United States attracts many international postdoctorate students/workers. Most U.S. international students are from Asia, with India and China 


\begin{tabular}{lccc}
\hline & \multicolumn{2}{c}{$\begin{array}{c}\text { Millions of international } \\
\text { students in: }\end{array}$} & $\begin{array}{c}\text { U.S. share of } \\
\text { international students } \\
\text { (\%) }\end{array}$ \\
\cline { 2 - 3 } Academic year & World & United States & 25.00 \\
$1974-1975$ & 0.6 & 0.15 & 36.25 \\
$1979-1980$ & 0.8 & 0.29 & 37.80 \\
$1984-1985$ & 0.9 & 0.34 & 32.50 \\
$1989-1990$ & 1.2 & 0.39 & 34.60 \\
$1994-1995$ & 1.3 & 0.45 & 26.80 \\
$1999-2000$ & 1.9 & 0.51 & 20.00 \\
$2006-2007$ & 2.9 & 0.58 & \\
\hline
\end{tabular}

Sources: For millions of international students worldwide, OECD (2008), Education at a glance: OECD indicators, box C31; for international students in the United States, Institute of International Education, figure 1B International Students and US. Higher Educational Enrollment Trends, http://opendoors.iienetwork.org/?p=131533.

Notes: Project Atlas reports somewhat smaller numbers: "In 2006, UNESCO estimated that over 2.5 million students were being educated at the tertiary level in countries other than their homes, up from an estimated 1.7 million in 2000" (http://www.atlas.iienetwork.org/?p $=46572$ ).

Table 11.9

Proportion of international students by academic level and major source country, 2006-2007

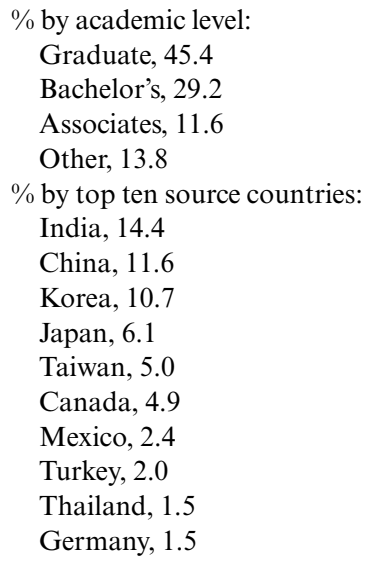

Sources: International Educational Exchange, Open Doors 2007; table 3 International Students by academic level, 2005 to 2006 and 2006 to 2007; figure 2A Top 20 leading places of origin of international students 2005 to 2006 and 2006 to 2007; http://opendoors.iienetwork .org/?p=113136 and http://opendoors.iienetwork.org/?p=113121.

Note: Total international student to the United States was 582,984 (over two-thirds were from Asia with nearly $85 \%$ from developing countries). 
Table 11.10

Share of U.S. degrees to non "citizens/permanent" residents, 1985-2005

\begin{tabular}{lrrrrrrrr}
\hline & \multicolumn{3}{c}{ All } & & \multicolumn{2}{c}{$\begin{array}{c}\text { Natural science/ } \\
\text { engineering }\end{array}$} & & \multicolumn{2}{c}{ Engineering } \\
\cline { 2 - 3 } Degree & 1985 & 2005 & & 1985 & 2005 & & 1985 & 2005 \\
\hline Bachelor's & 3.0 & 3.1 & & 5.4 & 5.2 & & 7.2 & 8.0 \\
Master's & 9.4 & 12.8 & & 27.2 & 38.6 & & 26.2 & 39.7 \\
Doctorate & 25.3 & 39.3 & & 33.1 & 50.9 & & 59.6 & 68.8 \\
\hline
\end{tabular}

Sources: Degrees, NSF, National Science Board (2008), Science and Engineering Indicators, 2008, chapter 2, tables 2-28, 2-30, and 2-31; Postdocs, enrollments, grad. table 2-22.

being the largest source countries. The foreign-born share of enrollments and degrees is particularly high in graduate science and engineering and increased greatly in those areas from 1985 to 2005 (table 11.10).

Although the foreign-born make up a much smaller share of undergraduate than of graduate students, they are an important source of immigrant scientists and engineers. There are three reasons. First, because the undergraduate student population is much larger than the graduate student population, the absolute number of foreign-born undergraduates is of similar magnitude to the absolute number of foreign-born graduate students. Second, foreign-born undergraduates are far more likely to do graduate work in the United States than foreign-born undergraduates educated outside the country. In 1993, 36.6 percent of foreign-born residents who obtained a master's degree in science and engineering had a U.S. bachelor's degree (over half of them also had a U.S. secondary school degree). Multiplying this by the 24.7 percent of S\&E master's degrees going to the foreign-born in that year, approximately 9.7 percent of all S\&E master's degrees were awarded to foreign-born persons with U.S. bachelor's degrees. This is 2.5 times the foreign-born share of U.S. bachelor's degrees in science and engineering. At the doctorate level, 19.1 percent of foreign-born residents with a science and engineering PhD had a U.S. bachelor's degree (with nearly half also having graduated from a U.S. secondary school). Given that the foreign-born had 40.6 percent of $\mathrm{S} \& \mathrm{E} P \mathrm{PhDs}$ in that year, about 10 percent of all $\mathrm{S} \& \mathrm{E} P \mathrm{PhDs}$ were awarded to foreign-born persons with U.S. bachelor's degrees. This is 2.8 times the foreign-born share of U.S. bachelor's degrees in science and engineering. ${ }^{11}$

What these statistics suggest is that attracting international students at the bachelor's level (and the high school level) raises the probability that those students continue their studies at U.S. institutions and eventually remain in the country to work. But the statistics do not establish that the relation is causal. It could be that the foreign-born undergraduates are selectively

11. The 1993 estimates are from Mark Regets, "Foreign Students in the U.S." PowerPoint presentation, June 27, 2005, Brussels Dialogue Meeting on Migration Governance, OECD. 
drawn from a population of persons who would end up working in the United States regardless of where they were educated. To determine whether studying in the United States or any other country leads to further study and immigration to the country of study requires some independent variation in opportunities to study in a foreign country, of the type that I discuss in section 11.2. To presage that discussion, there does indeed appear to be a causal link: attracting students to study in a country induces them to study and work later on.

In the aftermath of $9 / 11$, the academic and research communities feared that tightened visa requirements would reduce the number of international students in the United States. The State Department rejected more students applying for visas than in the past, particularly from China, and made it more difficult for international students to travel outside the United States. The number of international students applying to and enrolling in U.S. universities fell from 2002-2003 through 2005-2006, breaking an upward trend that stretched back at least from 1959-1960. But the State Department responded to complaints about the difficulties faced by international students and remedied many of the problems (National Academy of Sciences 2005). Even with the post $9 / 11$ drop, the United States attracted 560,000 or so international students in 2003 to 2005 , and the number increased from 2005-2006 to 2006-2007.

What factors lie behind the huge increase in international students and their choice of countries in which to study? Using a cross-section regression design, Rosenzweig (2006) found that the number of U.S. students obtaining visas in the early 2000s from different countries was larger the larger the population in the country of origin and the closer the distance to the United States, and was also larger the greater the number of universities in the students' home country and level of gross domestic product (GDP) per capita. He also reported that the number of visas was inversely related to the return to skills in the home country: the higher the skills in the home country, the less likely were students to come to the United States. The implication is that many come to the United States with the intention of remaining to work in the United States. This fits well with the fact that a large proportion of international students in science and engineering do eventually end up working in the country. But Hwang (2008) finds that analyses that look at changes in student visas by country are positively related with earnings differentials in the student's country, which implies that many may have chosen to study in the United States because returns to higher education are high in their home country (though they may later decide to remain in the United States).

\subsubsection{The University Sector}

The supply of university students and graduates is only part of the story of the growth of higher education around the world. The other part relates to the increased number or scale of the institutions of higher education that 
employ faculty and other staff to "produce" graduates. In many countries, the central government determines the number of places in departments to which students apply so that the distribution of graduates among fields depends on government policies. In the United States, state governments have been the major force in expanding the number of institutions of higher education, though student choices determine the distribution of graduates. In yet other countries - Korea, the Philippines - much of the expansion of higher education has come through the private sector. Australian universities actively recruit for international students, largely because the national government has reduced public funding (Marginson 2001; Welch 2002).

Expansion of higher education in the United States between 1960 and 2005 first took the form of large increases of enrollments in existing institutions and then of large increases in the number of institutions. Between 1960 and 1980, enrollments in institutions of higher education in the United States nearly tripled, from 3.3 million students to 12.1 million students. The number of institutions increased more modestly, from 2,008 to 3,231 (including two-year institutions) so that approximately two-thirds of the 1960 to 1980 expansion took the form of increased enrollments at existing institutions. ${ }^{12}$ Between 1980 and 2005, enrollments increased from 12.1 to 17.5 million - a 45 percent increase, while the number of institutions increased from 3,231 to 4,276 , by 32 percent. In this period, 86 percent of the expansion took the form of increased numbers of institutions ${ }^{13}$ - a lagged response to the huge growth of enrollments in the 1960s and 1970s.

What about the expansion of higher education worldwide? The International Association of Universities (IAU) provides information on over 16,000 institutions of higher education around the world (IAU 2008, 2009). In addition, several Internet sites provide data on universities outside the United States during the 1990s period of rapid enrollment growth (http:// univ.cc/; www.braintrack.com/about.htm). These data provide potentially detailed information on the development of mass higher education around the world that goes beyond this study but that gives some insight into the incredible expansion of the university sector worldwide. ${ }^{14}$ Table 11.11 records the names and years of founding (or of changes in the nature of an institution into a university) in two developing countries: Bangladesh and Chile. Many of the institutions in both countries were developed in the 1990s. In Bangladesh, the new institutions were public sector, but in Chile, there was an expansion of private-sector colleges and universities. Bangladesh has

12. Calculated using $\ln$ metric, the growth of enrollments was $1.30 \mathrm{ln}$ points, while the growth of the number of institutions was $0.48 \ln$ points.

13. Calculated using $\ln$ metric, the growth of enrollments was $0.37 \mathrm{ln}$ points, while the growth of the number of institutions was $0.32 \mathrm{ln}$ points.

14. The IAU data are in computer form but not publicly available as of 2008 , but earlier data may exist only in paper form. I am currently trying to get all of these data organized in research-friendly forms. 
Table 11.11 Universities in Bangladesh and Chile, 2004, by year founded (with multiple years reported due to changes in status comparable to founding)

\begin{tabular}{|c|c|}
\hline Name & Year founded \\
\hline \multicolumn{2}{|c|}{ Bangladesh universities } \\
\hline Bangabandhu Medical & $1965(1998)$ \\
\hline Bangabandhu Medical Agric & $1983(1998)$ \\
\hline Bangladesh Agricultural Univ & $1961(1972)$ \\
\hline Bangladesh Open Univ & 1992 \\
\hline BUET & $1947(1992)$ \\
\hline Chittagong & $1964(1966)$ \\
\hline Dhaka & 1921 \\
\hline HMDSTU & $1976(2002)$ \\
\hline Islamic & $1979(2000)$ \\
\hline Jahangirnagar & $1970(1972)$ \\
\hline Khulna & 1991 \\
\hline National University & 1992 \\
\hline Rajshahi & 1953 \\
\hline Shahjalal & 1987 \\
\hline American International & 1994 \\
\hline Ahsanullah & 1995 \\
\hline AUB & 1996 \\
\hline DIU & 1989 \\
\hline Dhaka & $1995(2000)$ \\
\hline EWU & 1996 \\
\hline Gono Bishwabidyalay & 1998 \\
\hline IUB & 1993 \\
\hline IUBAT & 1992 \\
\hline Islamic University of Techl & 1981 \\
\hline North South Univ & 1992 \\
\hline People's University & 1996 \\
\hline Queens & 1997 \\
\hline Asia Pacific & 1996 \\
\hline Univ Sci \& Tech. Chittagnong & 1992 \\
\hline \multicolumn{2}{|c|}{ Chilean universities } \\
\hline arturo prat & 1984 \\
\hline metropolitan of education & 1986 \\
\hline metropolitan of tech antofagasta & 1981 \\
\hline atacama & 1857 \\
\hline bio bio & 1988 \\
\hline chile & 1738 \\
\hline magallanes & $1961(1981)$ \\
\hline santiago chile & $1849(1981)$ \\
\hline talca & 1981 \\
\hline tarapaca & 1982 \\
\hline valparaiso & $1911(1981)$ \\
\hline Adolfo Ibanez & $1953(1989)$ \\
\hline Alberto Hurtado & 1997 \\
\hline Andres Bello & 1988 \\
\hline Autonomous Univ Christian & $1975(1988)$ \\
\hline
\end{tabular}



(continued)

\begin{tabular}{|c|c|}
\hline Name & Year founded \\
\hline Autonomous Univ of South & 1989 \\
\hline Bernardo O’Higgins & 1990 \\
\hline Bolivariana & 1988 \\
\hline Catholic-Cardinal Henriquez & $1990(1993)$ \\
\hline Catholic & $1888(1930)$ \\
\hline Catholic Univ of Holy Concept & 1991 \\
\hline Catholic Univ of Maule & 1991 \\
\hline Catholic Univ of North & $1956(1969)$ \\
\hline Catholic Univ of Temuco & 1991 \\
\hline Catholic Univ of Valparaiso & $1928(1961)$ \\
\hline Central & $1982(1993)$ \\
\hline Chile Adventist & $1965(1990)$ \\
\hline Diego Portales & $1982(1993)$ \\
\hline Federico Santa Maria Tech & $1932(1935)$ \\
\hline Finis Terrae & $1981(1996)$ \\
\hline Francisco De Aguirre & $1990(2001)$ \\
\hline Gabriela Mistral & $1981(1992)$ \\
\hline Ibero_American Tech & 1989 \\
\hline International & $1892(1988)$ \\
\hline Jose Santos Ossa & 1992 \\
\hline Las Condes & 1987 \\
\hline Mariano Egana & 1988 \\
\hline Maritime & 1990 \\
\hline Miguel de Cervantes & 1998 \\
\hline Panamerican & 1989 \\
\hline El Libertador & 1990 \\
\hline San Andres & 1994 \\
\hline San Sebastian & $1989(2001)$ \\
\hline Santo Tomas & 1988 \\
\hline Southern & 1955 \\
\hline Aconcagua & $1978(1989)$ \\
\hline Americas & $1988(1997)$ \\
\hline Andes & $1989(2001)$ \\
\hline Arts, Science and Comm & 1981 (1999) \\
\hline Arts and Social Sciences & 1982 \\
\hline Computer Science & 1989 \\
\hline Concepcion & $1919(1980)$ \\
\hline for Development & 1990 \\
\hline Mayor & $1988(1996)$ \\
\hline of the Pacific & 1990 \\
\hline of the Republic & 1988 \\
\hline of the Sea & 1989 \\
\hline VP Rosales Tech & $1982(1992)$ \\
\hline Vina del Mar & $1984(1990)$ \\
\hline
\end{tabular}


an Open University. The universities in both countries report connections with universities in advanced countries.

\subsection{Part II: Implications}

The globalization of higher education has implications for supply and demand in the labor market, for the U.S. university system, and for the economy writ large.

\subsubsection{Immigration and the Labor Force}

Increased numbers of foreign-born university graduates trained outside the United States and increased numbers obtaining degrees as international students in the United States provide new growing sources of highly educated workers for U.S. firms. By coming to the United States, these immigrants strengthen the country's comparative advantage in high-tech and university workforce-intensive sectors. At the same time, however, by augmenting the supply of highly educated workers in the United States and worldwide, the greater number of highly educated foreign-born persons reduce the payoff to investing in higher education in the United States. The supply of highly able programmers from India and other developing countries willing to work at lower pay than Americans has dampened the growth of the supply of programmers in the United States. Looking at PhDs, Borjas (2006) finds the increased number of foreign-born S\&E graduates in the United States reduces the employment opportunities and earnings of U.S.-born S\&E graduates (Borjas 2006), which presumably lowers U.S. supply.

The 1990s economic boom provides striking evidence of the extent to which immigrant scientists and engineers can increase the total labor supply of graduates in the United States in times of great demand. Census data show that from 1990 to 2000, the foreign-born share of bachelor's science and engineering graduates increased from 11 percent to 17 percent, that the foreign-born share of master's degree science and engineering graduates increased from 19 percent to 29 percent, and that the foreign-born share of doctorate science and engineering graduates increased from 24 percent to 38 percent, while the foreign-born share of those aged less than fortyfive nearly doubled from 27 percent to 52 percent. Nearly 60 percent of the growth in the number of $\mathrm{PhD}$ scientists and engineers in the country in the 1990 s came from the foreign born. Data from the Current Population Survey for the 2000s show that the foreign-born share remained in ensuing years as well. In 2005, the foreign born made up 18 percent of bachelor's S\&E workers, 32 percent of master's S\&E workers, and 40 percent of the $\mathrm{PhD}$ S\&E workforce, and continued to supply over half of doctorate scientists and engineers under the age of forty-five. Looking at all college graduates, in 2007, the foreign born were 18 percent of the U.S. college graduate 
workforce and 28 percent of the growth of college graduates from 2000 to $2007 . .^{15}$

As intimated in the earlier discussion of international students, a huge proportion of immigrant scientists and engineers come to the United States first as students. ${ }^{16}$ Table 11.12 shows that nearly 60 percent of all foreignborn scientists and engineers working in the United States obtained their degrees in the United States. The proportion of U.S. degree recipients among the foreign-born was larger at the PhD and master's level than at the bachelor's level, though even among bachelor's graduates, half of foreign-born S\&E workers in the United States were U.S. university-educated. The proportions obtaining degrees in the United States versus in their home or in other countries does, however, differ markedly by country. Many S\&E workers from India, the Philippines, the former Soviet Union, and the United Kingdom were educated outside the United States, whereas the majority of foreign-born S\&E workers from China, Taiwan, South Korea, Mexico, and Germany were educated in the United States. Because the United States accounts for about 10 percent of all $\mathrm{S} \& \mathrm{E}$ degrees granted in the world (about 8.5 percent of bachelor's degrees compared to 17.6 percent of $\mathrm{PhDs}$ ), if the country of degree was unrelated to the likelihood of working in the United States, 10 percent of the foreign-born scientists and engineers in the United States would have been U.S.-educated compared to the 60 percent who in fact were U.S.-educated.

What is the actual probability that U.S.-educated foreign-born scientists and engineers end up working in the United States? To estimate this statistic, I compare NSF estimates of the stock of foreign-born S\&E workers with highest degrees in the United States in the country to the cumulated number of the foreign-born who obtained a U.S. degree in the preceding thirty or so years at the doctorate, master's, and bachelor's levels. The NSF (NSB 2008, appendix table 3-8) reports that in 2003, the United States had 1.34 million foreign-born S\&E workers with a highest degree in the United States, of whom 176,000 had a PhD from the United States, 438,000 had a U.S. master's as their highest degree, and 723,000 had a U.S. bachelor's degree as their highest degree. These statistics are the numerator for my estimates.

15. The 2007 data are from the Bureau of Labor Statistics, Foreign Born Workers: Labor Force Characteristics in 2007 (http://www.bls.gov/news.release/pdf/forbrn.pdf). The 2000 data are from the Migration Policy Institute (2005), migration information source, table 1: Demographic, Social, and Labor Market Characteristics by Nativity: College-Educated Workers, Ages 25 to 64, Census 2000. (http://www.migrationinformation.org/Feature/feb05_spotlight _table1.cfm.)

16. Neither the Current Population Survey nor the Census ask where someone earned their degree, so they do not distinguish between international students who stay in the United States and immigrants who come with foreign degrees. The 2000 Census reported a much higher number of foreign-born S\&E workers than did the NSF's SESTAT data system because the latter counts foreign-born recipients of U.S. degrees but not immigrants with overseas degrees between Census years. The New American Community Survey asks an open-ended question about the specific major of bachelor's degree recipients. 
Table 11.12

Proportions of U.S. science and engineering workers that are foreignborn and the proportion of the foreign-born that have highest degree in the United States, $2005(\%)$

\begin{tabular}{lcc}
\hline Degree & $\begin{array}{c}\text { Foreign-born } \\
\text { share of workers }\end{array}$ & $\begin{array}{c}\text { Share of foreign-born } \\
\text { with highest degree }\end{array}$ \\
\hline Bachelor's & 15.2 & 54.3 \\
Master's & 27.2 & 68.5 \\
Doctorates & 34.6 & 64.00 \\
\hline
\end{tabular}

Source: National Science Board (2008, table 3-8).

To estimate the number of foreign-born persons who obtained $\mathrm{PhDs}$ in science and engineering doctorates from whom the 176,000 foreign-born but U.S.-trained doctorates came, I use the number of $\mathrm{PhDs}$ granted to persons who were not U.S.-born nor permanent residents from the Survey of Earned Doctorates between 1970 and 2003. ${ }^{17}$ There were about 250,000 such persons. Dividing the 176,000 estimated stock in 2003 by 250,000 suggests that about 70 percent of the $\mathrm{PhDs}$ in the thirty-three year period were in the United States in 2003. This statistic is of the same order of magnitude as Survey of Earned Doctorates data that show that 70 percent to 75 percent of foreign doctoral recipients plan to stay in the United States after they graduate (NSB 2008, indicators, table 2-33) and with Michael Finn's (2007) estimates that in the $2001 \mathrm{PhD}$ graduates cohort, 66 percent of foreign-born doctorates were working in the United States for at least two years and that 62 percent of the 1995 graduates were still working in the United States ten years later.

For masters' graduates, I estimate that about 600,000 noncitizen, nonpermanent residents obtained a degree between 1965 and 2003, a slightly longer period due to their being younger than doctorate graduates. Dividing the 438,000 estimated stock in 2003 by this number suggests that around two-thirds stayed to work in the country. For bachelor's graduates, I estimate that on the order of 550,000 noncitizens and nonpermanent residents obtained S\&E degrees in the United States from 1960 to 2003 (again a bit longer to allow for the younger age of these graduates). In this case, the 2003 stock of 723,000 exceeds the estimated number of foreign born persons with a U.S. S\&E bachelor's highest degree. While this comparison suggests that there are some serious problems with the bachelor's graduate statistics, it does not gainsay the conclusion that a huge proportion of international students who obtain U.S. degrees end up working in the country years later.

Turning to foreign-born S\&E graduates who obtain degrees overseas, the

17. There is a problem with using temporary residents because the United States gave permanent resident status to Chinese students following Tiananmen Square incident, and those students would be counted with U.S. citizens/permanent residents. 
NSF estimates that in 2003, there were 0.9 million foreign born S\&E workers with their highest degree outside the country. On the basis of estimates of the number of bachelor's and higher graduates outside the United States and the proportion of those who studied science or engineering, there were about 31 million university-educated $\mathrm{S} \& \mathrm{E}$ workers outside the country. ${ }^{18}$ Dividing the 0.9 million foreign-educated S\&E workers in the United States by the 31 million degree recipients, I estimate that approximately 3 percent of foreign-born S\&E workers with highest degrees outside the country immigrated to the country.

To what extent might the huge difference between the likelihood that foreign-born S\&E graduates with U.S. highest degrees end up working in the United States and the likelihood that a foreign-born graduate earning an $\mathrm{S} \& \mathrm{E}$ degree outside the country migrates to the United States reflect the causal impact of being an international student on immigration behavior, as opposed to selectivity of persons with greater desire to move to the United States? Lacking experimental or pseudo-experimental variation in studying in the United States to answer this question, I seek an answer in estimates of the causal impact of international study on a graduate's future location of work from analyses of the European Union's ERASMUS program (http://en.wikipedia.org/wiki/ERASMUS_programme). This program provides financial incentives to students to study outside their country for one or two terms. Comparing cohorts of students before and after introduction of the program and groups eligible and ineligible due to the timing of their university's involvement with the program, Parey and Waldinger (2008) estimated causal impacts on location decisions on the order of 20 percentage points - far below the huge difference in the proportion of international students who immigrate to the United States and the proportion of non-U.S.-trained graduates who migrate to the United States given in the above. Other studies of student migration and employment in the EU (Oosterbeek and Dinand 2009; de Grip, Fourage, and Sauerman 2008; Dreher and Poutvaara 2005) find similar orders of magnitude for the impact of being an international student and future work in a foreign country. As to the mechanism by which study abroad causally affects working abroad, Parey and Waldinger (2008, table 11) find that social factors in the form of a partner are important in leading former international students to work outside their home country and that assessments of career prospects also

18. My estimate is based on NSF estimates that 26 percent of the stock of university graduates in the world was in the United States in 2000 "or most recent year" (NSB, Science and Engineering Indicators 2008, figure 3-52). In 2003, 50 million persons aged twenty-five and over had four or more years of higher education in the United States (U.S. Census Bureau 2004, table 214). The supply of university graduates outside the United States was, thus, on the order of 150 million persons. From the statistics in table 11.2 of this study, I estimate that 27 percent of bachelor's graduates outside the United States are in science and engineering. This gives an estimate of 31 million science and engineering graduates outside the United States. 
influence the decision to work overseas, presumably by linking the students to potential future employers.

The estimated causal impact of foreign study on immigration decisions from the ERASMUS program is likely to understate the causal impact of being an international student in the United States on migration behavior. The reason is that the ERASMUS program is a smaller treatment than four to six or so years of study for a degree in the United States, during which time the student could very well build up job and social connections that could make returning home feel more like immigration than remaining in the United States. In addition, whereas students in the ERASMUS program move between countries with roughly similar standards of living, most U.S. international students are from developing countries such as China and India rather than from comparable advanced countries. The rates of staying for $\mathrm{PhD}$ graduates are much higher for persons from lower-income countries than for those from higher-income countries.

The increased number of university graduates overseas and of international students who return to their homeland will also create competition for highly educated U.S. workers. Increasing their stock of university graduates improves the ability of other countries to compete with the United States in high-tech and other sectors that use highly educated workers. With large numbers of graduates outside the U.S., multinationals are more likely to locate overseas research and development work and other activities that require university education. Consistent with this, between 1994 and 2004, research and development (R\&D) employment increased by 94 percent in the majority-owned foreign affiliates of U.S. multinationals, while employment in the parent firm increased by 39 percent. ${ }^{19}$

\subsubsection{The Impact of Globalization of Higher Education on the U.S. University System}

The growing number of students and universities in other countries impacts the U.S. university system in several ways. Increased numbers of bachelor's graduates from other countries raises demand for places in U.S. graduate and professional schools. If U.S. universities treat foreign and domestic applications equally, the increased share of bachelor's degrees outside the United States will reduce the proportion of U.S. graduates admitted to particular programs. In 2008, the bright U.S. graduate from, say, Haverford, must compete for admission to Berkeley, Harvard, Michigan, or Massachusetts Institute of Technology (MIT) with students from China, Brazil, India, France, Germany, and so on as well as with top graduates from Texas, Syracuse, Dartmouth, and so on. In July 2008, the Chronicle of Higher Edu-

19. In 1994 , R\&D employment was 92,400 in majority-owned foreign affiliates of U.S. multinational corporations (MNCs) and 591,200 in U.S. parent firm (http://www.bea.gov/ scb/account_articles/international/1296iid/table17.htm). In 2004, it was 179,300 in majorityowned foreign affiliates and 818,7000 in parent firm (Yorgason 2007, tables 1 and 3). 
cation reported that the three leading major undergraduate institutions for U.S. PhD programs were Tsinghua, Beijing, and Seoul National University. ${ }^{20}$ Given that the top U.S. graduate and professional schools have not increased the number of graduate slots much (Freeman, Jin, and Shen 2007), the chances of graduates of U.S. institutions gaining admission to these programs has been and is likely to continue to fall.

But this does not mean that overseas applicants push students from U.S. bachelor's programs out of postgraduate education. The United States has a large number of universities that have expanded graduate enrollments. The expansion of U.S.-born women into graduate programs occurred more or less simultaneously with increased foreign student enrollments. Many foreign-born graduate students enrolled at less-prestigious universities, which enabled those institutions to improve their graduate programs (Freeman, Jin, and Shen 2007). To the extent that the supply of U.S. students to graduate programs diminishes due to the increased attraction of masters of business administration (MBA) or law programs, bachelor's graduates from overseas will keep some graduate programs in business.

International ratings of universities place U.S. institutions at the top of the world tables. The Institute of Higher Education, Shanghai Jiao Tong University, rates eight of the top ten universities as American, nine of the next ten, and thirty-seven of the top fifty. (http://ed.sjtu.edu.cn/ rank/2005/ARWU2005_Top100.htm). In its league tables, the Times of London places more UK universities among the top, but the UK numbers still fall far short of those for the United States (http://www.timesonline .co.uk/tol/life_and_style/education/article502890.ece). Associated with the dominance of the U.S. university system is its ability to attract outstanding foreign-born scientists and engineers, many of whom first came to the country as international students, as noted. In 2003, a large proportion of full-time doctoral instructional faculty in research institutions in the physical sciences/math/computer sciences/engineering were foreign born - 47 percent compared to 38 percent in 1992 (NSB, 2008, appendix table 5-21).

Over time, foreign universities will improve their quality so that the expansion of higher education outside the United States will create greater competition for American universities in attracting international students. For American students and faculty, the benefit will be a greater number of quality universities at which to obtain an education or a job. The challenge to U.S. universities will be to remain world centers of excellence in spite of increased overseas competition. This presumably requires that they innovate in various ways, taking advantage of their "brand names," culture of openness, ties with business, and so on. Some U.S. institutions have developed

20. Jeffrey Brainard, "Graduates of Chinese Universities Take the Lead in Earning American PhDs," Chronicle of Higher Education, July 14, 2008, http://chronicle.com/article/Gradu ates-of-Chinese/41297. 
overseas branch campuses to increase enrollments in particular countries (for instance, Carnegie Mellon in the Qatar). This may work in some countries but not in others. In the early 1990s, about forty U.S. universities had branches in Japan, but the Japanese educational authorities did not accredit them and all but three have shut down.

Foreign universities, particularly from Australia and the United Kingdom, have been more active than U.S. universities in seeking international students as undergraduates. Some Australian universities award degrees to students who do part of their education at lower-cost universities in their home country. The Australian government gives preference in immigration to graduates from Australian institutions. British universities have more branches overseas than American universities, particularly in Commonwealth countries. In non-English-speaking countries, many universities have switched their education into English, which increases their attractiveness for international students. Among the developing countries, China's Project 985 policy for creating a number of first-rate universities of international advanced standing represents perhaps an extraordinarily bold effort to leapfrog a low-income country to the forefront of higher education. It involved providing sizable financial grants to nine universities - Beijing Fudan, and Nanjing among traditional universities and to Tsinghua and five other institutions oriented primarily to science and technology. In 2004, the government expanded financial support to an additional thirty institutions. While it will take time, and perhaps increased democratization of China for these universities to challenge the very best American universities, the Chinese university system has greatly improved its attractiveness to faculty and students worldwide. In fall 2008, the Chronicle of Higher Education reported that China had become the fifth top college destination for international students, particularly attracting those from Asia (Hvistendahl 2008).

In the face of global competition, it is difficult to imagine the United States maintaining the dominance it has had in the latter part of the twentieth century (just as it is difficult to imagine the United States maintaining its dominance of the global economy). But barring some horrific policies or events, I would expect U.S. universities to continue to rank among the world's leaders in higher education into the foreseeable future and, thus, to keep attracting high-skill immigrants to the country.

\subsubsection{Impacts on the Economy}

The increased number of science and engineering and highly educated workers around the world has two major positive impacts on the economy. First, it should accelerate the growth of scientific and technological knowledge and the economic progress that flows from this knowledge. One does not have to be a devotee of "the singularity" view of technological progress to believe that having three or so times as many university graduates, particularly in science and engineering, than a quarter century ago, the Internet 
to spread knowledge, and computers to perform calculations unimaginable two or so decades ago could produce a golden age for humanity. ${ }^{21}$ We benefit from advances in our understanding in biology or nano-technology or robotics or economics for that matter, regardless of whether the increased knowledge comes from the United States or other places or from U.S.-born persons or foreign-born persons. To the extent that taxpayers in some other country fund research and education, we win without paying for it. Second, the increased number of highly educated workers overseas should raise productivity in foreign countries, which, in turn, should reduce the cost of their exports to the United States. This will benefit all Americans who do not compete in producing those goods. If Romanian scientists and engineers figure out ways to improve the production of shoes, the price of shoes on the global market will fall, and the United States as a major importer of shoes will benefit.

But there is a negative side. The increased supply of university graduates in other countries will enhance their ability in the high-tech sectors that employ relatively many college graduates, where the United States has comparative advantage. In the context of the North-South model of trade in which the advanced North does the R\&D that produces innovative products and the developing South produces products based on low-wage labor, this competition will squeeze U.S. earnings and job opportunities. With more highly educated workers, developing countries should be able to increase their rate of innovation and their rate of imitation. The prices of U.S. exports in high-tech and other university-graduate-intensive sectors should decline, with adverse consequences for the workers in those sectors and for workers with similar skills elsewhere.

In some cases, given the lower cost of labor, the United States may lose its position as the major producer of high-tech goods or of the research and development on which they are based. The NSF (NSB 2008) data show that China has, in fact, increased its share of export markets in high-tech goods. The Georgia Tech index of the technical prowess of countries based on a variety of statistics shows a huge rise in the position of China's prowess. The index will surely show increases in the position of other developing countries in the next decade or two.

In response to the growth of highly educated workers worldwide, the United States can seek to attract international students on the notion that many will stay in the country as immigrants and can encourage high-skilled immigrants to come to the country. Given that the multinational firms in the forefront of technology can locate activities in the United States or offshore activities overseas, the policy issue for the United States would seem to be whether it is better to attract immigrant specialists or to have the multinationals offshore an increasing proportion of their work overseas. Which

21. http://en.wikipedia.org/wiki/Technological_singularity. 
is better for the United States-offshoring or immigration? Grossman and Rossi-Hansberg (2008) make a case for offshoring. Assuming that wages in the developing countries are lower for similar work than wages in the United States, offshoring costs less than the same work done by immigrants in the United States. Offshoring is equivalent to an improved technology that allows U.S. workers to do their tasks better. Foreign-born workers compete on the offshorable tasks but not on other activities with Americans for whom they are substitutes. By contrast, immigrants compete with Americans in all sorts of jobs, including those in nontraded sectors. Taking a broadly similar approach, Ruffin and Jones (2007) argue that under some conditions, it is even desirable to give our best technology to the low-wage foreign countries because we will then get the products back at the lowest cost. In the case of science or engineering, better to have an inventor doing their work overseas at lower cost than than doing it in the United States at higher cost.

But can the same person do as good work in a developing country as in the United States? There is diverse evidence that the huge pay and productivity difference between workers in the United States and in developing countries cannot be explained by human capital-labor or capital-labor ratios or any other observable measure, for that matter. Analyzing research papers, MacGarvie and Khan (2009) show that the number of papers written is higher for nominally similar international students in the United States than for those whose fellowships make them return to their native countries. The implication of these findings is that the same person working with the same capital produces more in the United States than in most other countries. Why? One possible reason is the United States's business and work culture, which is difficult to replicate. But whatever the reason, the greater productivity in the United States implies that immigration raises output more than offshoring and, thus, is to be preferred on that criterion.

Does the productivity of U.S. workers benefit more from immigration or offshoring? Working in direct contact with someone would appear to raise productivity more than buying their goods because of the greater likelihood of learning about work activity from them. Kremer and Maskin's (2006) model of the mixing of low- and high-skilled workers does not deal with immigration and offshoring, per se, but it gives conditions for the sorting of workers between advanced and developing countries that shows that the answer to the productivity question will depend on relative numbers and productivities of skilled and less-skilled workers outside and within the United States as well as on the strength of complementarity reflected in the production function.

\subsection{Conclusion}

This paper has documented the spread of higher education around the world. It has shown that the rising proportion of young persons going to 
college in advanced countries, which has risen above those in the United States in some countries, and in the huge populous developing countries has greatly diminished the United States's share of the world's university students and graduates. Because international students make up roughly half of university graduate immigrants, the ability of U.S. universities to attract the world's best and brightest international students has important consequences for its success in attracting immigrant talent.

The growing number of foreign-born persons getting $\mathrm{PhDs}$ outside the United States as well as in U.S. universities will undoubtedly diminish the gap between U.S. universities and those in other countries. The world ranking of top universities in 2020 is likely to include many more from other countries. Increasingly, new knowledge will come from workers outside the country, but there is much the United States can gain from this. We do not know whether the United States will do better through immigration or through offshoring of some university graduate-level work. My guess is that by educating some of the best students in the world, attracting some to stay in the country, and positioning the United States as an open hub of ideas and connections for university graduates worldwide, the country will be able to maintain excellence and leadership in the "empire of the mind" and in the economic world more so than if it views the rapid increase in graduates overseas as a competitive threat.

\section{References}

Boarini, Romina, and Hubert Strauss. 2007. The private internal rates of return to tertiary education: New estimates for 21 OECD countries. OECD Working paper no. 591. Paris: Organization for Economic Cooperation and Development.

Borjas, George. 2006. Immigration in high-skill labor markets: The impact of foreign students on the earnings of doctorates. NBER Working Paper no. 12085. Cambridge, MA: National Bureau of Economic Research.

Council on Competitiveness. 2005. National summit on competitiveness: Investing in innovation. Washington, DC: National Association of Manufacturers.

Dreher, Axel, and Panu Poutvaara. 2005. Student flows and migration: An empirical analysis. IZA Discussion Paper no. 1612. Bonn, Germany: Institute for the Study of Labor.

Duke University, Master of Engineering Management Program. 2005. Framing the engineering outsourcing debate: Placing the United States on a level playing field with China and India. Durham, NC: Duke University.

Edin, Per Anders, and Robert Topel. 1997. Wage policy and restructuring: The Swedish labor market since 1960. In The welfare state in transition: Reforming the Swedish model, ed. Richard Freeman, Robert Topel, and Birgitta Swedenborg, 155-201. Chicago: University of Chicago Press.

Finn, Michael. 2007. Stay rates of foreign doctorate recipients from U.S. universities 2005. Oak Ridge Institute for Science and Education. 
Freeman, Richard B. 1971. The market for college-trained manpower. Cambridge, MA: Harvard University Press.

. 1975. Overinvestment in college training? Journal of Human Resources 10 (3): $287-311$.

1976. The over-educated American. New York: Academic Press.

Freeman, Richard B., Emily Jin, and Chia-Yu Shen. 2007. Where do new US-trained science-engineering $\mathrm{PhDs}$ come from? In Science and the university, ed. Ronald G. Ehrenberg and Paula E. Stephan, 197-220. Madison, WI: University of Wisconsin Press.

Gomory, Ralph, and William Baumol. 2007. Global trade and conflicting national interests. Cambridge, MA: MIT Press.

Grip, Andries de, Didier Fouarge, and Jan Sauermann. 2008. What affects international migration of European science and engineering graduates? Research Memoranda no. 006. Maastricht, The Netherlands: ROA, Research Centre for Education and the Labour Market.

Grossman, Gene M., and Esteban Rossi-Hansberg. 2008. Trading tasks: A simple theory of offshoring. American Economic Review 98 (5): 1978-97.

Hvistendahl, Mara. 2008. China moves up to fifth as importer of students. Chronicle of Higher Education, September 19.

Hwang, Jung Eun. 2008. MIT or Tsinghua? A panel data analysis of the determinants of domestic higher education and international student mobility. Bachelor's thesis, Harvard College.

International Association of Universities. 2008. The international handbook of universities. 20th ed. Hampshire, UK: Palgrave Macmillan.

2009. World higher education database. New York: Palgrave MacMillan.

Kremer, Michael, and Eric Maskin. 2006. Globalization and inequality. http:// www.economics.harvard.edu/faculty/kremer/files/GlobalizationInequality Oct06.pdf.

MacGarvie, Megan, and Shulamit Khan. 2009. How important is U.S. location for research in science? Boston University Working Paper.

Marginson, Simon. 2001. The global market in foreign higher education: The case of Australia. Paper presented at Association for Studies in Higher Education (ASHE) 26th annual conference, Richmond, Virginia.

McKinsey Global Institute. 2005. The emerging global labor market: Part I. White Paper no. 2005-06-01. New York: McKinsey Global Institute.

Ministry of Education of the People's Republic of China. 2007. Gross enrollment rate of schools by level. Beijing. Ministry of Education of the People's Republic of China. http://www.moe.edu.cn/edoas/website18/level3.jsp?tablename $=2233$ \&infoid $=33487$

National Academy of Sciences (NAS). 2005. Policy implications of international graduate students and postdoctoral scholars in the US. Washington, DC: NAS Press.

National Science Board (NSB). 1998. Science and engineering indicators 1998. Arlington, VA: National Science Foundation. 2004. Science and Engineering Indicators 2006. Arlington, VA: National Science Foundation.

. 2006. Science and Engineering Indicators 2006. Arlington, VA: National Science Foundation.

. 2008. Science and Engineering Indicators 2008. Arlington, VA: National Science Foundation.

National Science Foundation (NSF). 1993. Human resources for science \& technology: The Asian region. NSF no. 93-303. Arlington, VA: NSF. 
1996. Human resources for science \& technology: The European region. NSF Special Report no. 96-316. Arlington, VA: NSF.

Organization for Economic Cooperation and Development (OECD). 2004. Internationalisation and trade in higher education: Opportunities and challenges. Paris: OECD.

2005. Education at a glance 2005: OECD indicators. Paris: OECD. 2007a. International migration outlook 2007. SOPEMI 2007 ed. Paris: OECD.

2007b. Science, technology and industry scoreboard 2007. Paris: OECD. 2008a. Education at a glance: OECD indicators. Paris: OECD. OECD.

2008b. Main science and technology indicators (MSTI) 2008-2 edition. Paris:

Oosterbeek, Hessel, and Webbink Dinand. 2009. Does studying abroad induce a brain drain? Economica, forthcoming.

Parey, Matthias, and Fabian Waldinger. 2008. Studying abroad and the effect of international labor market mobility: Evidence from the introduction of ERASMUS. IZA discussion paper no. 3430. Bonn, Germany: Institute for the Study of Labor.

Rosenzweig, Mark. 2006. Global wage differences and international student flows. Washington, DC: Brookings Institution.

Ruffin, Roy J., and Ronald W. Jones. 2007. International technology transfer: Who gains and who loses? Review of International Economic 15 (2): 209-22.

Schofer, Evan, and John W. Meyer. 2005. Worldwide expansion of higher education. Center on Democracy, Development, and the Rule of Law, Stanford Institute on International Studies Working Paper no. 32.

U.S. Census Bureau. 2004. Statistical abstract of the United States: 2004-2005. 124th ed. Washington, DC: U.S. GPO, December.

- 2007. Statistical abstract of the United States: 2008. 127th ed. Washington, DC: U.S. GPO.

Wadwha, Vivek, Gary Gereffi, Ben Rissing, and Ryan Ong. 2008. Getting the numbers right: International engineering education in the United States, China, and India. Journal of Engineering Education 97 (1): 13-25.

Welch, Anthony. 2002. Going global? Internationalizing Australian universities in a time of global crisis. Comparative Education Review 46 (2): 433-71.

Yorgason, Daniel. 2007. Research and development activities of U.S. multinational companies. Survey of Current Business (March):22-39. 